\title{
Guillermo Verdecchia and the frontera in contemporary Canadian diasporic writing
}

\author{
Guillermo Verdecchia y la frontera en la literatura \\ contemporánea canadiense de la diáspora
}

\section{Darja Zorc-MaVer ${ }^{*}$ IGOR MAVER ${ }^{* *}$}

University of Ljubljana, Slovenia.

igor.maver@guest.arnes.si

\begin{abstract}
Contemporary diasporic literary authors in Canada are today mostly seen $C_{\text {as }}$ transcultural authors in the global cross-border English-speaking cultural collage space and in the Canadian multiethnic society. The socalled minority literature has in effect become part of the mainstream and no longer merely a veneer of the much coveted and publicly proclaimed, albeit not always practically effectual multiculturalism. Canadian diasporic writing thus has to be considered anew within the context of a new interAmerican transborder integration, which has substantially changed the field of identity politics, the very concept of ethnicity and the need for its redefinition, as well as the various cultural/literary practices of a collective and individual dynamic identity construction. Canada has come a long way from the model of the Canadian cultural mosaic, a concept used to express the much sought unity through diversity, and it is today proud of its selfimage as a multicultural country. While some writers and critics are clearly supportive of the policy of multiculturalism, others again find it reached its limits in fostering some sort of self-imposed ghettoization and refer to
\end{abstract}

* Darja Zorc-Maver is an Associate Professor at the Faculty of Education, University of Ljubljana. Along with social pedagogy she also researches multiculturalism and transculturalism.

** Igor Maver is a Professor of English at the Faculty of Arts, University of Ljubljana. He has taught in the USA, Germany and Australia and has published in the field of post-colonial literatures and diasporic literatures. 
the multicultural fallacy, which may, in fact, fragment Canadian society rather than create and solidify a Canadian nation in the global world. There is also the question of the exotic ethnic Other which, according to some critics, emerges when the marginalized minority ethnic writers emphasize their exoticism to create a certain ethnic stereotype to fit the definition of a certain expected ethnic group upon which state funding frequently depends.

Diasporic writing generally asserts a sense of belonging to the locality in which the transplaced people have grown up, and, at the same time, expresses the specificity of the actual historical experience of being 'ethnic' in a particular immigration society. Diasporic writers, who had migrated voluntarily or involuntarily, use literature to broker, affiliate and translate the places, peoples, cultures and languages to work through the ethical, political and affective ambivalences of diasporic identities and subjectivities. At the beginning of the new millenium a new phase of mass movements of people creating new diasporas, border(land)s, transcultural and transnational identities has been emerging globally: these new displacements and border crossings have created new diasporic literary discourses. Diasporas today in the contested in-between spaces are part of the process of the construction of Us vs. the Others, but the problem lies in the question as how to identify the former and the latter, since binary constructions clearly no longer seem to work. The lived experience of the locality of Home, combined with that of cultural memory of remembering and therefore 'belonging', is however very different from that of an imaginary or, better still, imagined homeland. The innovative and groundbreaking analyses of Chicano/a intellectuals in the USA (Gutiérrez-Jones) gave rise to the theorists of the border with Gloria Anzaldúa at the forefront. In her seminal book Borderlands/La frontera: The New Mestiza (1987) she examined the suppressed and often violent aspects of the Texas and México border and introduced the spatial metaphor of the frontera or borderlands. Frontera is thus in her view the border space which enables to essentially accept the various contradictions per se and to refuse the impossible attempt to unify and synthesize them, hence it turns all the existing social, racial, ethnic and gender contradictions into a source of strength and unity. The concept of the frontera has since enabled many writers, in Canada as well, to see their own culture not as a dominant narrative but rather from the point of view of heterogeneity and messiness, subalternity and hybridity: it enabled to focus on the conceptual possibilities related to borders, border-crossings, and borderlands, frequently not even a geographical but an imaginary space of contact.

A major representative contemporary Canadian author regarding 
diasporic/borderland subjectivity, originally from Argentina in South America who came to Canada as a small child, is Guillermo Verdecchia especially, albeit clearly not exclusively, with his monodrama Fronteras Americanas/American Borders, which won a Chalmers Award and the 1993 Governor General's Award for Drama. In the play a displaced diasporic subject struggles to de- and re-construct a home between two cultures, while with great humour exploding the images and renegotiating clichés built up around Latinos and Latin America not only in Canada but the USA as well. The protagonist is split in two personas, 'Wideload' McKennah/ Verdecchia, 'Anglo' vs. 'Latino', wittily ponders 'Saxonian' attitudes as well as the cultural shock he experiences upon his return to South America, crossing the frontera yet again, only to come to the paradoxical conclusion in his poetic imagination that it is really the border within himself that must be crossed and embraced, for maps are really always just metaphors and not the territory: "And you? Did you change your name somewhere along the way? Does a part of you live hundreds or thousands of kilometers away? Do you have two countries, two memories? Do you have a border zone?" (Verdecchia, 1997: 78). Verdecchia uses stereotyping in order to reduce cultural differences and even resorts to a simplistic caricature of the Canadian Latino identity, which he subsequently tries to deconstruct. This instance of border-zone Canadian literature and his innovative use of 'Hispanish', as a language of resistance, reveals the fact that he is lost, which began "in France, Paris, France, the Moveable Feast, the City of light, where I lived for a couple of years. En France ou mes étudiants me disaient que je parlais le français comme une vache Catalan(e)-. En France ou j'étais etranger, un anglais, un Argentin-Canadien, un faux touriste. Paris, France where I lived and worked illegally, where I would produce my transit pass whenever policemen asked for my papers. In France, where I was undocumented, extralegal, marginal and where for some reason, known perhaps only by Carlos Gardel and Julio Cortázar, I felt almost at home" (Ibid., 28). When the speaker in the play (Verdecchia) eventually comes back to Calgary in Canada, "this Noah's ark of a nation" from his one-time home, South America, the Other America, as he calls it, it suddenly revealingly strikes him as in an epiphany: "I am not in Canada; I am not in Argentina. I am on the Border. I am Home. Mais zoot alors, je comprends maintenant, mais oui, merde! Je suis Argentin-Canadien! I am a post-Porteno neo-Latino Canadian! I am the Pan-American highway!" (Ibid., 75).

Act Two of the monodrama Fronteras Americanas/American Borders significantly addresses the tango as the quintessential South American/ 
Argentinian contribution to the world that crossed the borders of the Americas as well. Throughout the whole play important auditory colour imagery of music, which is perceived by the sense of hearing rather than sight, from a host of South American authors and performers (Mano Negra, Los Mariachi, Los Lobos, Atahualpa Yupanqui, Astor Piazzolla and Kronos Quartet, Ramiro's Latin Orchestra, Carlos Santana, Steve Jordan, Milladoiro, Plácido Domingo, Dino Saluzzi, Aníbal Troilo). Tango, however, perhaps born of the gaucho's crude attempts to waltz, is

music for exile, for the preparations, the significations of departure, for the symptoms of migration. It is the languishing music of picking through your belongings and deciding what to take.

Music for men and women thin as bones.

Music for your invisibility...

Music for a day in the fall when you buy a new coat and think perhaps you will live here for the rest of your life, perhaps it will be possible, you have changed so much, would they recognize you? Would you recognize your country? Would you recognize yourself?

Wideload: Basically, tango is music for fucked-up people... (Ibid., 59-60).

The author concludes that the tango was only reluctantly accepted in Europe, but that it has not been entirely domesticated outside of Argentina, that it is namely impossible to shop or aerobicize to tango "porque el tango es un sentimiento que se baila" (Ibidem.).

Verdecchia's monodrama ends on a prophetic note (somos todos Americanos), directly addressing the audience, his fellow Canadians, who all live in the border zone of the Americas, where the border line between Canada and the US is not perceived as so radical as the one with Latin America that begins at the Mexican border:

Every North American, before this century is over, will find that he or she has a personal frontier with Latin America.

This is a living frontier, which can be nourished by information but, above all, by knowledge, by understanding, by the pursuit of enlightened selfinterest on both parts.

Or it can be starved by suspicion, ghost stories, arrogance, ignorance, scorn and violence (Fuentes, 1985: 7)

The movement forward is no longer a movement towards the centre, but 
rather a future trajectory towards the border, which has in fact overnight become the centre, so that in this case it is the border that 'strikes back' "Ladies and gentlemen, please reset your watches. It is now almost ten o'clock on a Friday night - we still have time. We can go forward. Towards the centre, towards the border" (Ibid., 78). Crossing borders (people, capital, information) challenge the notion that a national community is necessarily bounded by its geographic borders, which of course also applies to its culture and literature discussed here, for some people's lives unfold in essentially diasporic settings, where class, race and citizenship play an extremely important role. Borders have acquired an increased mobility and multiplicity and there has been their continual dislocation, one that is closely linked with a differential regulation of migration and citizenship. The recent migratory diasporic spaces that the new diasporic Canadians inhabit and lend them their distinctive voice and vision mark deterritorialization and increasingly also reterritorialization, which blurs the borders of nations and nation-states, as it can be seen in Fronteras Americanas. At the same time these reterritorializations (somos todos Americanos) and transnational/ borderland diasporic movements seem dangerously close to and are indeed inextricable from the (neocolonialist) reterritorializations of global capital, division of labour, production and profit. Guillermo Verdecchia, a Canadian of Argentinian provenance, only a few after the success of his play Fronteras Americanas/American Borders for the first time tried his hand at short stories which came out under the title Citizen Suárez (1998): the stories are, like his early play, essentially about people lost between countries and languages, in their complex citizenship caught between desire to run away and to belong. He wrote and starred in a short film adaptation of Fronteras Americanas called Crucero/Crossroads, which was shown at international film festivals and received several awards.

Canada has long been searching for its own national identity and this Sysiphian search was compared to "a dog chasing its own tail" (Atwood, 1995: 8). The concept of the ethnic mosaic within the multicultural paradigm in Canada has resulted in artists of various ethnic backgrounds promoting their own -and thus Canadian culture of the country- as in a kind of Grand Hotel Canada (this includes such internationally renowned authors and Man Booker Prize winners as Michael Ondaatje, Margaret Atwood, and Yann Martel). Neil Bissoondath, who arrived in Canada from Trinidad only in the early 1970s has always struggled against the label of a Trinidadian (-Indian) Canadian writer. His views on multiculturalism in Canada are much debated and controversial for some people (Bissoondath, 
1994). In his essays he claims that the policy of multiculturalism (mosaic) has been downright disastrous for the country and for immigrants themselves and that it has now reached a point when it has to be seriously reexamined. Some degree of integration is today necessary and legitimate to expect, for ethnic/migrant groups have tended to isolate themselves, in one way or another, too much from the majority population in the midst of which they live. Bissoondath writes that Canadians encounter each other's multicultural mosaic tiles mainly at festivals, which are reduced to the simplest theatre at the level of "a folkloric Disneyland". In most of the multicultural literature, he continues, ethnic stereotypes are only reinforced:

There are those who find pleasure in playing to the theme, those whose ethnicity ripens with the years. Yet to play the ethnic, deracinated and costumed, is to play the stereotype. It is to abdicate one's full humanity in one of its exotic features. To accept the role of ethnic is also to accept a gentle marginalization. It is to accept that one will never be just a part of the landscape but always a little apart from it, not quite belonging. In exoticizing and trivializing cultures, often thousands of years old, by sanctifying the mentality of the mosaic-tile, we have succeeded in creating mental ghettos for the various communities (Bissoondath, 2006).

In describing the position of racial minority Canadian writers, some critical voices have denounced multiculturalism as not being adequate enough. Multiculturalism should and indeed to a large extent has become more allinclusive as regards the Native, Black and Asian peoples in Canada and in the recent years it has come a long way. The concept of multiculturalism, of course, greatly varies regarding its deployment in individual national contexts. If in countries like Canada and Australia (since the 1970s) it refers to government programmes designed to equalize and empower minority ethnicities, in México it means the official encouragement of the identities of individual indigenous groups in the country, while in Brazil it is treated with suspicion and an ambivalent attitude. In France social critics attack it as either "a recycling of 1960s third worldist radicalism", for the Center/ Right and for the left it represents "a cunningly disguised form of American imperialism" (Stam and Shohat, 1995: 296). Regardless of how one sees multiculturalism in terms of the perception of the value of non-mainstream literatures of the ethnicised body, it is clearly today a hybrid between the actual practice and policy and the idealised view of a tolerant ethnic plurality within a national framework, thus a 'desired' discourse. Multiculturalism 
should not be dismissed as an entirely unworkable, utopian concept, although it is today a greatly problematic issue in need of some not only cosmetic revision with a view of transculturalism and transnationalism.

Contemporary Canadian writing by diasporic authors from a wide variety of diasporic communities traces their connections to various locales in Africa, Asia, the Caribbean, South America or Eastern Europe, etc. and perceives Home as several locales, which is, however, at the same time deeply embedded in the collective cultural memory of a migrant and her/his own personal biography (or that of their parents or grandparents). Indeed, contemporary Canadian diasporic literary production is becoming pluralized and globalized by transcending individual traditional categories of Canadianness especially as regards the Canadian locale as well as the volatility of cultural memory. There has recently emerged a pronounced shift of emphasis in contemporary Canadian diasporic writing, for many new texts are set outside Canada and feature reversed migration back to a home place by a Westernized/Canadianized protagonist, who does not so much want to return home as to write back home (e.g. Anita Rau Badami, Michael Ondaatje, Janice Kulyk Keefer, Rohinton Mistry, M. G. Vassanji, etc). This points to the fact that there is no unitary national narrative tradition in Canadian fiction and that Canada today, as a culturein-process, as another diasporic switching-point (Appadurai, 1996: 171), largely expresses itself today in literary texts as an imagined community. Displacement and the fluid transnational and borderland post-ethnic diasporic identity, identity being at the very heart of the concept of Home, show a dynamic and shifting global view of some of the best Canadian new diasporic authors. This includes the literary Latino frontera world of Guillermo Verdecchia, where his pronounced auditory sound colouring of South and Central American music serves as a linking element on his spiritual journey and identity search between his two 'homes', Argentina and Canada, respectively, from say "La Bamba" to Plácido Domingo, with music serving as one of the characters in the play.

\section{REFERENCES}

Anzaldúa, Gloria. 1987. Borderlands/La Frontera: The New Mestiza. San Francisco: Spinsters/Aunt Lute. 1999, Rev. ed., New York: Aunt Lute Books.

Appadurai, Arjun. 1996. Modernity at Large: Cultural Dimensions of 
Globalization. Minneapolis: University of Minnesota Press. Atwood, Margaret. 1995. Strange Things. London: Clarendon Press. Bissoondath, Neil. 1994. Selling Illusions: The Cult of Multiculturalism in Canada. Markham, Ont.: Penguin. 2006. "No Place like Home", 18 October de 2006. (On line) Disponible en: http://www.newint.orgissue305/multiculturalism.html. Consulta: 28.09.2011.

Fuentes, Carlos. 1985. Latin America: At War with the Past. CBC Massey Lectures. Toronto: CBC Enterprises.

Stam, Robert and Ella Shohat. 2005. "Traveling Multiculturalism: A Trinational Debate in Translation". En Ania Loomba et. al (eds). Postcolonial Studies and Beyond. Durham NC and London: Duke University Press, pp. 293-316.

Verdecchia, Guillermo. 1997. Fronteras Americanas/American Borders. Vancouver: Talon Books. . 1998. Citizen Suárez. Vancouver: Talonbooks. 